\title{
Contemporary Transformations in the Brazilian Popular Catholic Festivals: the Case of the Holy Divine Spirit Festival (Festa do Divino)
}

\author{
Renata Siuda-Ambroziak ${ }^{1}$ (D) Fabiene Passamani Mariano ${ }^{2}$
}

Received: 30 June 2021 / Accepted: 26 September 2021 / Published online: 19 October 2021

(c) The Author(s) 2021

\begin{abstract}
The Azorean families, wherever they migrated, brought their cultural background in which there clearly stood out celebrations of the annual festival of the Divine Holy Spirit. The Festa do Divino, as it is called in Brazil, has turned, in places where they originally settled down, into one of the most famous religious festivals of the Brazilian Popular Catholicism. However, due to some contemporary sociocultural factors, mostly linked to the more and more frequent application of the laws of market economy to the sphere of religion and also to the visible liberalization of the religious festivals' "rules of conduct," it has been recently suffering from some important modifications. In this article, we present and analyze such changes, basing on the study of celebrations of this popular religious tradition in four different municipalities of four different states of Brazil.
\end{abstract}

Keywords Feast of the Divine Holy Spirit · Popular religiosity · Brazil · Religious festivals

\section{Introduction}

Traditional popular religiosity is an overwhelming phenomenon in Brazilian Catholicism, with religious beliefs and practices inserted into a system of its own logic, stressing utilitarian and practical solutions in relations with the transcendence (Zaluar 1983: 22-23). Treated by many scholars as "a particular way that faith is

Renata Siuda-Ambroziak

r.siuda@uw.edu.pl

Fabiene Passamani Mariano

fabiene.mariano@ifes.edu.br

1 American Studies Center, Institute of the Americas and Europe, University of Warsaw/PostGraduate Program in Social History of the Rio de Janeiro State University, Warsaw, Poland

2 Federal Institute of Espirito Santo - Ifes/Laboratory for Migration Studies at the Federal University of Espirito Santo, Viana, Espirito Santo, Brazil 
lived by a social group" or "a religious movement centered on the cult of saints" (Steil 2016: 60), traditional popular religiosity still exercises a strong dialectic impact over Brazilian culture and society, sometimes competing against the institutional church or opposing its official doctrines. But although some tensions are at times unavoidable, in many places, especially in local parochial communities, popular religiosity is still common to the vast majority of the faithful and is not necessarily combated nowadays by local priests, often even more "progressive" in their tolerance towards modern sociocultural phenomena than many of their more traditional parishioners-a lingering effect of the Vaticanum II "enculturation evangelization policies," which approved the Catholic popular religiosity with elements of hybridism and various local syncretisms.

In such a context, the abundance of local popular religious festive celebrations in contemporary Brazil has constituted a privileged ground for examining peculiar religious dynamics in which individuals and local communities are immersed (Guarinello 2001: 972). Brazilian popular religiosity is an aggregator of a wide symbolic imaginary depicted in various forms of many devotional festivals, which, against all the advances of the contemporary world, still represent a significant affective importance in the lives of the faithful. One of such traditional celebrations is the Festa do Divino, closely linked with the Azorean immigration settled in Brazil. It usually has a duration of a week, approximately, and it refers to the biblical passage about the descent of the Holy Spirit upon Holy Mary and the disciples of Jesus Christ (the Pentecost). The beginning of it is marked by a choice or appointment of the imperadores do Divino (the emperors of the Holy Spirit) taking place at the end of the ongoing celebrations-thus, the beginning of the next Festa is at the same time the end of the previous one, making it cyclical and annual.

According to Leal (2017), the Festa do Divino has had everywhere the same basic configuration of the ritual script, with few variations, preserving the coronation ceremony of the emperors as its culmination. However, the traditional Brazilian Festa do Divino always reflects also all the important sociocultural changes taking place in a given local community and/or in a Brazilian society as a whole. Inserted in the Brazilian reality, the Festa do Divino presents itself as a collective stage for a series of important religious representations, deeply involved in the reality in which it is immersed and susceptible to its changes and transformations.

Costa (1999:25) points out the variety of existing interpretations about the origins of the Festa do Divino due to the complexity of the cult accentuated by the remoteness of its creation. Leal (2017) describes three basic proposals of such narratives, supporting the so-called Elizabethan version as the most plausible and widely accepted. This narrative places the origin of the Festa in Portugal, during the reign of King Dinis and Queen Isabel (Elizabeth), at the turn of the thirteenth and fourteenth centuries, linking the queen, later beautified in 1516 and canonized in 1742, to the construction of the church of the Holy Spirit in Alenquer and the creation of the first festive ritual as a result of a promise made to the Holy Spirit in favor of restoring peace between her husband and her son, the heir to the throne. It is said that the queen promised the Holy Spirit that, if peace returned to her kingdom, she would donate her own crown to the temple and institute a special day dedicated to the festivities. The queen is said to have fulfilled her promise: on the Pentecost 
Day, accompanied by some nobles, she took her crown in solemn procession to the church of the Holy Spirit, thus choosing the "Empire" (the place of the Festa) and beginning the first celebrations. The Festa included the processions and the symbolic coronation of a poor, made by the queen with her own crown, and also the sharing of a great banquet with all the participants. From then on, the religious Festa began to take place annually, always respecting the same date on which the first one took place, i.e., the day of the Pentecost.

Since its beginnings, the Festa do Divino has not only been a religious celebration-its participants do worship and pray, but they also eat, drink, talk, attend shows, and dance. Therefore, just as any other secular festivity scenario, it can be treated like a mirror for reflecting incessant dialectic influences, disputes, conflicts, and negotiations of different character, causes, and results. Thus, Bakhtin's considerations (1987: 7-8) are very opportune when he affirms that festivities have always expressed a conception of the world of their participants and maintained a direct relationship with community life, constituting an important mechanism of social and interpersonal relations, but also reflecting all possible changes in the rules of conduct and the level of their acceptance.

The connection of the religious sphere with purely secular phenomena and processes may sometimes become a controversial issue, especially when economic perspective is applied to the religious dimension. Nevertheless, both spheres may be approached dialectically rather than separately, emphasizing the explanatory potential of both to understand the "religious sector of the market" (Berger 2005; Stark and Bainbridge 2000; Stark and Finke 2002). Sometimes economic terminology has been borrowed by scholars to explain the functioning of "entrepreneurship of faith," a quest for a profit, a "transactional or barter" approach to religious phenomena, in which consumers make their choices basing on a "favorable rate of exchange" and religious suppliers come up with new offers (Siuda-Ambroziak 2019); other times, the laws and rules of the market economy have been being applied to the religious sphere to show how the reality of the postmodern world has changed and how consumerism, mass culture, and the necessity of instant solutions have influenced not only our way of life, but also our imaginary representations of God, such as "Jesus from Disneyland" (Moore 1994). However, both indicated above perspectives highlight a clear analogy in functioning of religious and economic spheres and both of them will be, to some extent, taken advantage of in the paper to show how the Festa do Divino organizers are trying to make it appealing in order to attract participants and resources ("sell the product") and how the participants contribute towards the Festa ("buy the product").

When we reflect about the history and the contemporary realizations of the Festa do Divino in Brazil, we can see the complexity of transformational processes and changes in its organizational and realization modes. The hypothesis that we present is that the Festa, despite being one of the most traditional religious festivals in Brazil, of Azorean origin, has suffered in the last decades many modifications in conformity with the current social and cultural transformations, mainly linked to the spread of the rules of the market towards the religious sphere and a general liberalization of the rules of behavior. Thus, some points for discussion that seem necessary are as follows: What are the main modifications/transformations that have occurred in 
the Festa in the last decades? How and why do participants and organizers explain/ justify/approve of or criticize them? To what factors do they/can we attribute these transformations?

In the paper, we relate to the Festa in order to trace some of the mechanisms responsible for its current modifications in Brazil. To do so, we use data obtained by means of documentary and bibliographical research, as well as semi-structured interviews (oral history methodology) in Viana/ES. When developing the contextualization of the Festa, we select, in order to provide enough material for analysis, four municipalities in four different states of the Federation: Mossâmedes, in Goiás; Mogi das Cruzes, in São Paulo; Gravataí, in Rio Grande do Sul; and Viana in Espírito Santo.

\section{Varieties of the Festa do Divino in Brazil}

The research by Leal (2017:11), referring to the annual occurrence of the Festas, points to their presence in almost all Brazilian territory, indicating their importance for the Brazilian "cultural geography." However, in spite of the original date, which was set on the Sunday of Pentecost, fifty days after Easter, in Brazil, the time of the Festa relates nowadays more often to the specific rhythm of local life, sometimes other important events in the community, not necessarily linked to the Catholic liturgical calendar. Oftentimes, especially in rural areas, the Festa is purposefully transferred to September or October so that it takes place after harvesting. In many places in Brazil, the Festa has become easily transferrable to practically any date agreed upon and fixed by the leaders of the local parochial community. Due to the multiple processes of such temporal modifications and the fact that in each place the Festa has been acquiring some local differentiating hybridizations, a saying "a cada canto seu Espírito Santo" (on each corner a different Holy Spirit) has been coined, showing a great diversity present in the ways of carrying out celebrations (Leal 2017:58; Costa 2008).

In general, the symbolism of the Divine used in Brazil is similar to that used in the Azores and other places of the settlement of the Azorean immigrationthe crown, the dove, and the flag of the Divine-but they may vary from region to region. In Brazil, although the title of "emperor" predominates in relation to the main actors of the Festa, sometimes it is substituted by "festeiro" or "mordomo." In some localities, the roles of emperors may be played traditionally by children or adolescents, sometimes by a married couple only, in other places-people coming from two different family backgrounds. Besides the role of emperor, the Festas add other important characters to their performance, for instance, folias do Divino, which are musical bands going from door to door and collecting tributes for the organization of the celebration. In Maranhão, the musical part of the festivities is performed by the Caixeiras do Divino (the cashiers of the Holy Spirit), devout ladies accompanying all stages of the ceremony (Pacheco and Gouveia 2005:2). In Baixada Maranhense and in São Luís, the Festa occurs in Afro-Brazilian temples (terreiros), especially of Tambor de Mina cult. According to Araújo (1964:31), the celebration of the Divino 
in Maranhão is linked mostly to the black population, and rituals dedicated to the Holy Spirit coexist with sacrifices offered to African deities.

Thus, the rituals adopted in the Festas do Divino in Brazil can actually vary a lot, depending on the region, as well as the number of extra events and social roles added to it by the organizers. In some places, the ceremonies have been preserved in a more discreet and intimate format, dispensing with luxury or any sign of ostentation. In others, especially those with some tourist appeal, real spectacles are currently held, with ornaments, costumes, scenography, music, and lavish ceremonies, which may cause a significant expenditure. But, on the other hand, they may also constitute a relevant income for the tourist industry and for the parish-a well prepared Festa is considered a great tourist attraction.

The way food circulates in the Festas held in Brazil is also nowadays quite varied. Meals open to the public coexist with restricted access ones, of indoor or outdoor character, free or charged. Originally the food was always prepared according to the Azorean recipes, but nowadays, it usually follows local culinary traditions, sometimes already "globalized" (Leal 2017:62). In some localities, as in the Feast of the House of Azores of São Paulo (CASP), the food served is still related to the maintenance of the immigrants' traditions: Azorean rump, Azorean stew, and the traditional Divino soup.

Similar to what happens with the food, the ritual sequence of the Festas in Brazil also varies in its modes of composition according to local customs and tastes. Sometimes celebrations dedicated to the Divine Holy Spirit are articulated with other local traditions, as in the case of the Cavalhadas, traditional equine fight of the Christians against the Muslims in the Pirenópolis Festival, of the Congados (traditional Afro-Brazilian street processions) in the festivals of the interior of Goiás, or the celebrations linked to the Day of the Dead, that occur in the interior of Maranhão, among other examples that reaffirm the amalgamating capacity that this festival represents in the Brazilian territory (Brandão 1985:165).

There are also celebrations that distance themselves from more traditional models and present themselves in more unpredictable forms, as occurs with the Marabaixo and the Sahiré, studied by Pereira (1989). The Marabaixo is related to groups of African descent from Amapá and Amazonas and consists of the practice of dances and songs traditionally linked to the Festa do Divino. The Sahiré, in turn, practiced by indigenous groups from the Northern region (Amazonas, Pará and Amapá), was a widespread ritual, which went into decline in the twentieth century, existing today in a very restricted form. It consisted of the execution of dances, songs, and the ceremonial circulation of food, in which the Divine, represented by the crown of the Holy Spirit, occupied a prominent place. According to Leal (2017:65), these and other similar cases represent great diversification and cultural improvisation in the Festa do Divino in Brazil. Besides the rituals, which are recreated from the contact with the local culture, the organizational contexts of the Festa do Divino may also differ from their original form. In Brazil, originally the organization of the festivities depended almost solely on the emperors (or festeiros) and on the support of their family and neighbors. In some cases, the festivities could also be organized by brotherhoods. And sometimes the local priest may have had the upper hand and the final word-the Catholic Church's involvement is seen, since Vaticanum II, as 
a tool for the "religious enculturation" of indigenous and Afro-descendant groups, which suggests that the idea of the participation of clergy in the Festa organization circulates easily in many progressive ecclesiastical sectors as a part of their liturgical arsenal (Leal 2017:66).

As a symbolic recognition for the amplitude reached in Brazil, the Festas have been increasingly attracting the interest of local political and intellectual elites. This fact can be proven from processes of registration of the celebrations as intangible heritage by the IPHAN (Institute of National Historical and Artistic Heritage), whether at national, state, or municipal level. This is, for instance, the case of the Festa in Pirenópolis, GO and of Paraty, RJ registered as intangible heritage of Brazil by the Institute of (IPHAN) and the Festas in Santa Catarina recognized as intangible heritage by the state or the Festa of Piracicaba, SP, registered as municipal intangible heritage. The registrations of the Festa do Divino as intangible heritage are recent and valid initiatives, considering the importance of the tradition and its value as a sociocultural asset. However, it should be also noted that it is only a symbolic recognition and that such an act, by itself, does not guarantee financial resources, nor the continuity of the tradition.

Aiming at deepening of our research, we will concentrate further on the modalities and recent transformations in the Festa de Mossâmedes, in Goiás; the Festa de Mogi das Cruzes, in São Paulo; the Festa de Gravataí, in Rio Grande do Sul; and the Festa de Viana, in Espírito Santo. The approach in question aims at possible comparisons facilitating further conclusions on the contemporary sociocultural transformations of traditional popular religiosity connected to the festivals.

\section{The Festa do Divino in Mossâmedes}

According to Brandão (1985), the Festa do Divino is a very common religious event in many agricultural communities in the Center-South region of Brazil, situated halfway between a "church festival" and a "people's party." It used to take place every last Sunday of the month of August, that is, completely outside of the Catholic liturgical period. In principle, the only justification given for this date was the viability of the time in relation to the cultivation of cereals. In August, the harvests of seasonal crops such as rice, corn, and beans have already completed their cycle, and the region experiences the annual drought, with consequent reduction of agricultural work. In this way, the end of the festival signals the resuming of work in the fields, throughout the region.

The person responsible for the general organization of the feast receives the name of Imperador do Divino (or festeiro). Formerly, both the emperor and his assistants were chosen by means of lottery prepared with the names from a list of candidates. However, the lottery no longer exists, and currently the choice is made by a local priest, who chooses three men-three emperors, who are supposed to act in partnership both in the collection of funds and in the disbursement of own resources for the realization of the Festa. Besides the budgetary part, they also share other obligations, among them preparation of the rituals, in collaboration with the priest and a 
"court of helpers" formed by people chosen by the priest, who assist the emperors in the organization of the Festa.

To participate in the feast performing some kind of a role, one must meet some prerequisites, such as the generosity towards the local community and active participation in the church. Officially, a good economic condition is not a reason for the choice of the candidate; however, according to Brandão (1985:188), on the lottery list, there practically appear only rich people. Besides them, it is worth noting the involvement of civil authorities, due to a visible process of bureaucratization of the event. For example, the processions today have to be authorized by means of issuing of a special permit. In addition, such permits are necessary for the assembly and operation of the stalls that sell food and other products during the Festa. Therefore, among the agents that organize and control the festival, three groups stand out: the emperors and their court; the church representatives; and, finally, the municipal authorities, including the mayor and the chief of the local police.

The festivities respect the scheme found in other popular religious festivals held in the interior of the state of Goiás, since the mid-eighteenth century. Brandão (1985) classifies the main events in three groups: "Folia do Divino," rituals of traditional music bands collecting donations linked to the local popular religiosity; "Festa da Igreja," set of rites of the Catholic Church commanded by the Parish; and the "Rancho Alegre," the profane part of the Festa. However, every year, more and more conflicts between the popular promoters of the festival, the ecclesiastical agents of the parish, and the local authorities are intensified, sometimes putting the organization of the Festa itself at risk. Brandão (1985) calls attention to the fact that originally the popular "folia" was considered the main ritual of the festivities of the Holy Spirit in Mossâmedes, and the entrance of the four flags through the old square in front of the church of São José was regarded as the most important moment of the whole feast. He argues that the pressures of the ecclesiastical agents weakened, or even sometimes excluded this popular part from the program of the Festa. His studies report different positions of priests who at times support and at othersoppose the ritual. At the end of the 1970s, there happened a real crisis between the organizers of the feast and the church: on the occasion, the local priest ordered the door of the temple to be closed in order to avoid the entrance of the folias with flags inside the church. Upon arriving, the flag carriers asked to open the door for them, but, apparently, no ceremony had been prepared to receive them.

In the past, the main flag used to be carried around the church square in a solemn procession before being raised to the top of the mast (Brandão 1985:183). However, like the folia, this ritual tends to be progressively pushed away to the second plan. Brandão (1985:190) states that the festival underwent more significant changes in the last five years of his research than in all its 195 years of existence, and these took place in spite of a comparative geographical isolation of Mossâmedes. However, he also remarks that the religious life of Mossâmedes had developed for a long time practically "without a priest" in view of a small number of ecclesiastical agents distributed in the region. 
Fig. 1 Cartaz digital da Festa em Mossâmedes em 2019, source: Facebook Prefeitura de Mossâmedes (https://www.faceb ook.com/cidadedeMossamedes/ photos/a.1383135565330954/ $2212143302430172 /$ ?type $=$ 3\&theater. Acessed 15 de june 2019)

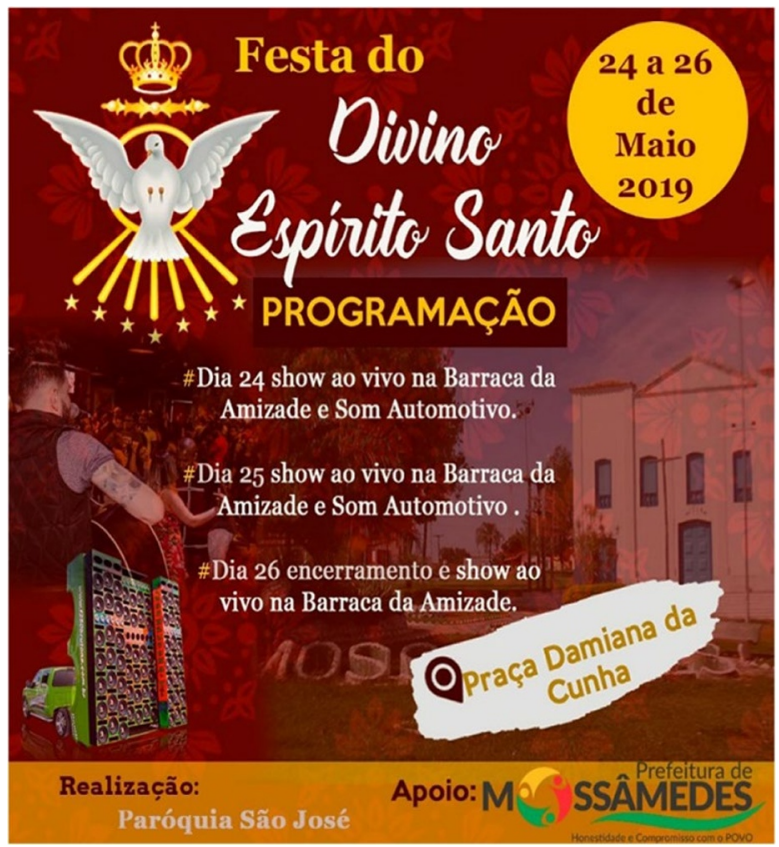

In 2018, we consulted the website ${ }^{1}$ of the Municipality of Mossâmedes to update information on the Festa. We found out that since then, it has been replaced in August by the festival in honor of the Patron Saint Joseph. A poster of the Festa found on one of the social networks in $2019^{2}$ presented only information about the cultural program, without mentioning any type of religious rituals (Fig. 1).

\section{The Festa do Divino in Mogi das Cruzes}

In this section, we will present the Festa do Divino held in Mogi das Cruzes, SP, since the middle eighteenth century, taking as a reference the studies of Moraes (2003), who analyzed it in relation to the mass culture, looking at its complexity from a perspective of extensive network of factors and relations (social, economic, political, and cultural).

The Festa lasts for ten days, beginning forty days after Easter and ending on the Pentecost Sunday. Its preparation begins a year before, with the choice of the emperor and empress of the Divine according to an indication of the current emperors: They put down names of couples available to take over, and from among the nominated, the local bishop chooses one. They are usually middle or upper-middle class people who have the time and resources to dedicate to preparing the Festa.

\footnotetext{
1 https://www.facebook.com/pg/cidadedeMossamedes. Acessed 17 de july 2018.

2 https://www.facebook.com/cidadedeMossamedes. Acessed 15 de june 2019.
} 
For instance, as a way to attract younger generation, the emperors are responsible to go around the "subimperials," which are secondary forms of empire, assembled in schools and university, with an objective to gather new adepts, prospective heirs to the tradition and to extend the symbolic domain of the Feast. According to Moraes (2003: 55), this invention is responsible for the growth of the popularity of the Festa in the last years.

The local impact of the Festa do Divino in Mogi das Cruzes at the beginning of the twenty-first century made it attract sponsorship on the part of big businesses, even multinational companies. ${ }^{3}$ This fact, solving possible financial dilemmas, made, in turn, the perpetuation of the traditional folias collecting donations totally dispensable, practically finishing with this important part of popular commemorations.

The resources are today enough for the organizers to provide in a municipal school a free community meal to all the participants. According to Moraes (2003:77), among the sponsors are such companies as Banco do Estado de São Paulo, Coca-Cola, Kaiser, Companhia de Papéis Suzano, Universidade Brás Cubas, and Eroles Turismo. In order to provide a stable, institutional link with the sponsors, there was created a formal association as a legal entity: a Associação Pró-Divino, which maintains a very well elaborated website, where the main news of the Festa do Divino can be accessed. ${ }^{4}$ After a quick consultation to the programming of the event in 2019, we verified that the main details of the festivities described by Moraes (2003) remain practically unchanged. In the cited webpage, besides information about the history, programming, and other news, some information can be accessed about past festivities, as demonstrated in the following poster (Fig. 2).

The emperor, among other responsibilities, is in charge of making or commissioning a flag of the Divine, exclusively for the Festa under his management. The main idea is always to surpass the beauty of the previous year's flag. The flag, kept secret, is officially revealed and blessed during the first official act of the Festa, that is, the opening of the Empire with presence of the local political and religious authorities - the commemorations are officialized by law 2.890, of February 25, 1985, and inserted in the Tourist Calendar of the Festivities of the Municipality (Moraes 2003:96).

\section{The Festa do Divino in Gravataí}

The first official record of the Festa do Divino de Gravataí, in the Book of Records of the church of Nossa Senhora dos Anjos, refers to the year 1859. However, between the 1970s and 2002, the commemorations were not held, and they were resumed only after 29 years of nonexistence. In the resumption process, some elements were updated based on the celebrations that occur in Terceira Island, Azores (Cruz 2018).

In the time preceding the long interval, between the end of the 1960s and beginning of the 1970s, the Parish Nossa Senhora dos Anjos passed through

\footnotetext{
3 http://www.festadodivino.org.br.

${ }^{4}$ http://www.festadodivino.org.br
} 
Fig. 2 Cartaz digital da Festa do Divino de Mogi das Cruzes/SP, source: Associação Pró-Divino (2019)

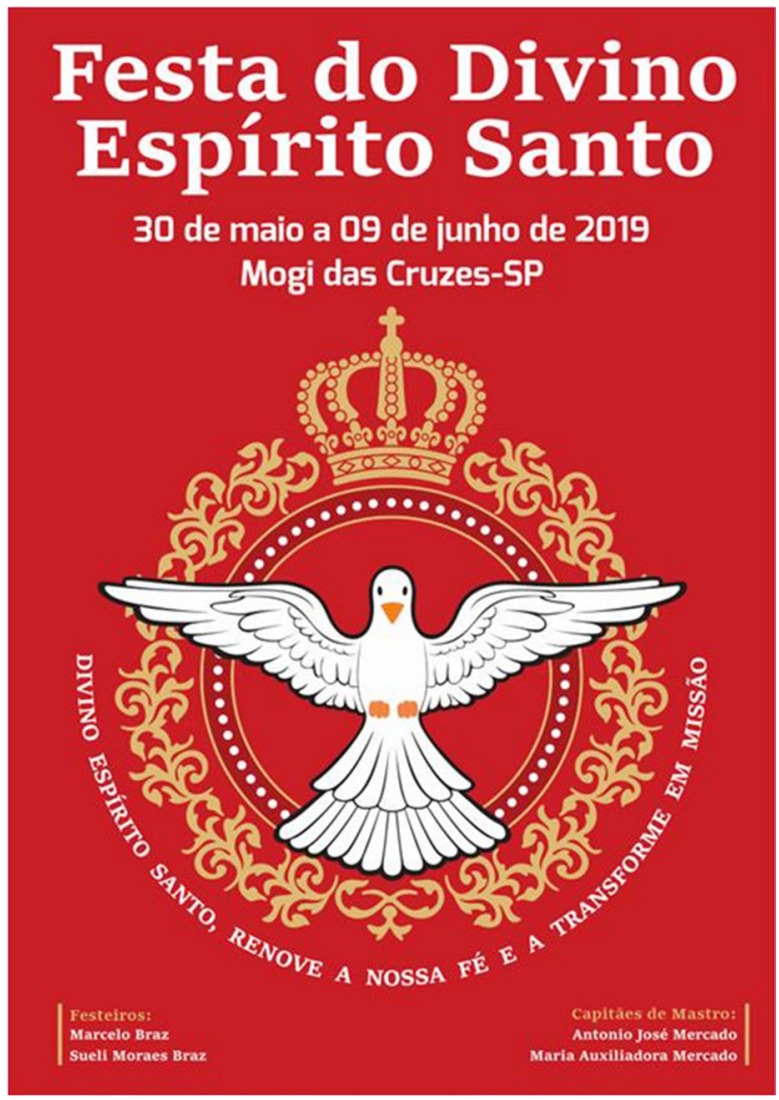

serious economic difficulties, and these were controlled thanks to the financial resources raised precisely with the Festa do Divino Espírito Santo, which became the main source of income for the church. Cruz (2018) indicates that, from the year 1963, the new vicar could additionally count on the support of the Military Police and the City Hall, and the resources raised with the festivities were also intended for the completion of the local hospital. Therefore, the procession of flags and folias collecting donations was extended and began to travel through other neighborhoods and outskirts of the city of Gravataí.

According to Cruz (2018), the death of 62 generous elderly donors in 1964 and the consequent fall in the collection of financial resources impacted the Festa directly in 1965. To resolve issues related to the programming and reduce the direct costs of the Feast, the parish made partnership with the Ministry of Education and Culture (MEC) and the National Service for Industrial Training (SENAI), offering technical courses to the community during the Festa, as mentioned in the Book of Records. In 1967, two factories were installed in the city, causing changes in the local society and consequently in the way of celebrating the Festa. One of them refers to the idea of celebrating in a more "modern" way, 
with a dinner in an "American" style, since at the time US culture was regarded as a symbol of modernity. This new proposal was so successful that the organizers had to repeat it, making the 1972 Festa the biggest ever held in Gravataí.

However, at the end of 1972, due to some disagreements with the archbishop, the vicar of the parish was transferred, and a new priest took over, which caused, together with the decision to stop the reconstruction works of the church, dissatisfaction and divisions within the community of the faithful. It resulted in 1973 in the disruption of the continuity of the Festa. According to the new vicar opinion, contained in the Book of Records of the parish, the Festa do Divino was not held due to some serious omissions and lack of interest of the committees appointed for this purpose. The festivities were only resumed a few decades later, in 2002, after the time of a substantial growth of the city, population increase, and generational change (Cruz 2018). It happened on the occasion of the commemoration of 250 years of Azorean immigration. As a result of the Azorean culture appreciation, the "new" Festa do Divino was inserted in official Gravataí festivity calendar, increasing the municipality promotion in tourism.

In the past, the Festivities in Gravataí were organized by local brotherhoods under the direct coordination of the priest. Nowadays, the organization of the festivities became a joint responsibility between the Parish Nossa Senhora dos Anjos, the municipal government, and the Casa dos Açores do Rio Grande do Sul, among other collaborating institutions. The Festa started to appeal to and involve a much bigger popular participation-it is worth highlighting the activity of the "Friends of the Divine," an association of former emperors, who came together with the objective of supporting and preserving the realization of the Festa in Gravataí.

Among the changes, there are also the forms of financing the festivities. Before, the collections of donations were restricted to the folias and other spontaneous contributions from the local community. Currently, these resources continue coming from donations but also from the sponsorship of local businesses and industries. This was highlighted by Cruz (2014) when analyzing, among other things, the graphic material used in promotion of the Festa, including recordings started from 2012, under the responsibility of the Municipal Art and Culture Foundation (FUNDARC), one of the main promoters of the Festa of the Divine Holy Spirit in Gravataí. The ritualistic set of the Festa in Gravataí went at that time through significant changes with the main objective to make it more dynamic, so that it could be transformed into a better tourist "product." In this sense, it is worth mentioning the substitution of novenas by triduums, thus reducing the number of festivity days from nine to three, and the inclusion of daily dinners, followed by cultural presentations. Such initiatives, as it is believed, help socialization between the participants, contributing towards the mercantilization of the Festa in a sense of providing income for the community members and boosting local tourism industry. It is towards such goals that a whole cultural program is developed, held nowadays at the headquarters of the Casa dos Açores do Rio Grande do Sul (CAERGS) and not in the church square anymore. Another important detail to be considered is the cultural hybridism present in this event. In the menu of lunch, instead of the traditional Azorean dishes, there appeared barbecue, traditional churrasco (Cruz 2018). 
The tradition of the Festa do Divino in Gravataí establishes obvious connections between religiosity and local economy, which also made the festival included in the municipal calendar of events, expanding its visibility as a touristic symbol of the city.

\section{The Festa do Divino in Viana}

The Festa do Divino Espírito Santo in Viana was held for the first time in the year 1817 (Balestrero 2012). In Viana, our research was not based on bibliography, but participative observation and interviews with 16 community members, classified in three categories: priests, members of the Festa organization team, and former emperors and empresses (some interviews have been used for previous analysis: Siuda-Ambroziak, Mariano 2020). One of the religious persons interviewed for the sake of our research was Father Ademilson Schimidt, who served as parish priest in Viana between 2004 and 2008. The other one was Father Luís Oggioni, parish priest of Viana between 2010 and 2018. The interviewees from the organizing team included Ludson Gonçalves de Jesus, 35 years old, journalist and teacher, member of the parochial communication team; Maísa Lourdes da Silva, 51 years old, retired teacher, who had already acted as general coordinator of the parish and, at the time of the interview, performed the function of a secretary to the general coordination of the Parish; Diva Lyrio Salles, 72 years old, responsible for the cleaning team of the church and decorating the crown of the Divino with red roses; Felícia Vieira Pimentel, 78 years old, retired teacher, member of the food team for the Festa; Cláudio Pimentel, 55 years old, retired policeman working as a musician; and Paulo Roberto Pimentel (Paulinho Pimentel), 62 years old, auctioneer at the Festa. In the semistructured interviews, they were asked about their experience with the Festa and reflections on its current transformations and modifications.

Marineuza Carvalho narrates that she has participated in the Divine Feast since she "could remember." She recalls that, during her childhood, the family lived in the rural area and that, when the Festa time arrived, her mother would separate the best clothes of everyone in the family to wash and iron them. The idea was for everyone to be well dressed to take part in the most important religious event, the Festa do Divino: "That's the way it used to be. Today people wear anything" (Carvalho 2018).

When she recalls the Festa do Divino of her childhood and compares it with the current Festa, Marineuza also points out that, nowadays, the Festa has more attractions; however, much of the religious essence has been lost. She points out that people were more fervent when it came to devotion of the Holy Spirit (Carvalho 2018).

Marineuza believes that her children also will continue collaborating in the Festa organization; however, she does not see them as mature enough yet for the position of emperor or empress. She recalls that she herself only started thinking about it when she was around 57: "when I was younger, I did not accept it. Who knows, maybe my children when they are around 50 years old, will also decide to put their name forward?" (Carvalho 2018). 
Nilza Carvalho Cavati continues the legacy of her family by actively participating in the organization of the Festa do Divino. In the interview, she emphasized her experience in the Catholic Church based on the education she received from her parents: "Daddy raised us in such a way that we attended all kinds of saints' feasts" (Cavati 2018a). Out of five daughters of Nilza Carvalho and Otomar Cavati, three have already acted as empresses of the Divino: Vera Lúcia Cavati, in 1979; Maria Luiza Cavati, in 2007; and Ana Maria Cavati, in the year 2015. The other two daughters of the couple, Vanilza Cavati and Valéria Cavati, despite not having acted as empresses, say that they have already registered their names; however, they have not been chosen yet.

Besides the daughters, one of the grandsons of the couple, Eric Cavati Alcântara, son of Vanilza Cavati, has already acted as emperor of the Divino during his preadolescence, in the year 2008.

Vera Lúcia Cavati was the first daughter of the couple to act as empress in the Festa do Divino. In her testimony, Vera Lúcia relates that this occurred while she was still a child and that it was her father who put her name down for the lottery, which now is no longer possible to do.

Our informants emphasize the importance of financial issue linked to the Festa. According to them, the funds raised during the Festa enable the parish to continue specific projects, such as the restoration of the church Nossa Senhora da Conceição and the expansion of the Pastoral Center. However, they also point out that people in the past were much more fervent in their faith, and this was also reflected in the great number of people who participated in the procession (Cavati 2018a).

Márcio Oliveira was the emperor of the Divino in the years of 1979 and 2006. He relates that, in the year of 2005, he went to the Festa with his children, and he felt sad when he saw the patio of the church practically empty compared with what it used to be like when he was a child. Before leaving, he put his and his mother's name to compete for the emperors of the next year. During the organization of the 2006 Festa, Márcio went to almost all the farms in the municipality to collect gifts and donations. He explains that without enough resources providing for traditional abundance and attractions, the Festa would not have been successfully brought back to life (Oliveira 2018a). For Márcio, raising funds for the church is one of the goals of the Festa do Divino; however, in his understanding, even more important would be to involve all the families in daily participation in the activities of the church. According to Márcio, since his childhood, the festival has basically followed a traditional model, with masses and processions: "it is logical that things have changed a lot. Today the attractions are much more modern, but the basic traditions were kept: lunch, auction, bingo and even Paulinho Pimentel as auctioneer" (Oliveira 2018a).

One example of hierarchical modification in the Festa organization is the acceptance for less well-off people to act in positions of prominence: the emperors are chosen randomly from among all the names put forward for the lottery. They have to, obviously, collect the funds for the organization purposes, but not necessarily provide them themselves. However, as we could observe, the social control over their activities is very strong-actually, they do not seem to have too much of an autonomy in the Festa preparations. They are provided with a ready script of actions that need undertaking, and it is supposed to be obeyed without questioning. 


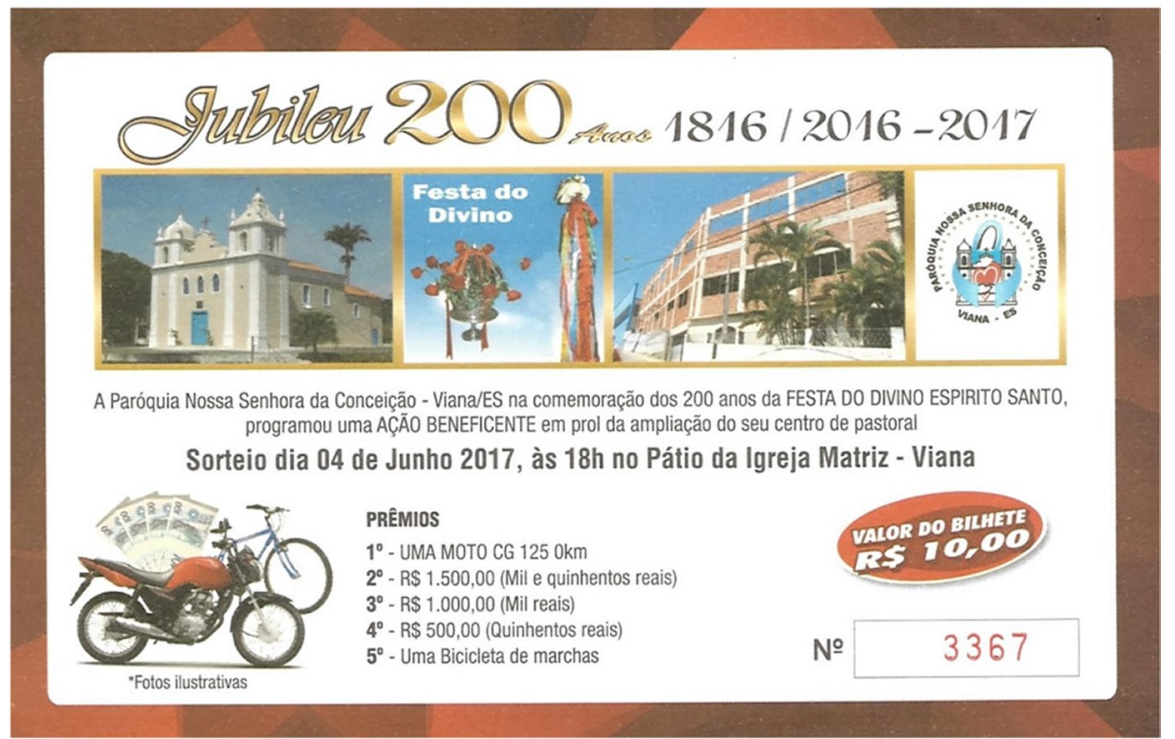

Fig. 3 Bilhete da "Ação entre amigos" da Festa do Divino em Viana no ano de 2017, source: Author' archive (2017)

This is a major characteristic that distinguishes the old and the new Festa: formerly, the emperors enjoyed total autonomy in the conduction of the festivities, and the priest's function was restricted just to the execution of rituals, such as masses, blessing of foods, and coronation ceremony. Gonçalves (2017) makes a very interesting remark about the role of the emperors nowadays: "today they are just symbols, they have no autonomy. The structure practically eliminates them."

For Ludson, the participation of the emperors does not correspond to the real role they should play, because the control imposed by the church contributes to the extinction of the tradition. He believes that if the emperors do not have autonomy to decide about the Festa, they become simple puppets: "So, why, if they cannot take any decision, do the emperor and empress exist?" (Gonçalves 2017).

In this aspect, Maísa Lourdes da Silva also reports that the emperors do not decide on anything, but explains the reasons for such a situation: if the emperors had total autonomy, they could do things that conflict with the church and downplay religious significance of the Festa. For example, in one situation, they invited a musical band "Soxotão," famous for its sexualized lyrics containing swearwords and the Parochial Council ordered, at the last moment, for it to be removed from the program. The problem was raised also because of the name of the band making allusion to the female sexual organs (Silva 2018).

Besides raising funds for the realization of the festival, the emperors are responsible for the commercialization of the "Action among Friends"- a kind of raffle, in which the person buys a ticket and this number gives the right to compete for the drawing of various gifts, for example, television sets, smartphones, 
tablets, or even cash prizes. Currently, the perceived success of a Festa is directly linked to the financial result it provides (Fig. 3).

In the 2017 edition of the Festa, one of the goals was the collection of funds for the completion of the Parochial Center. However, this goal usually varies from year to year. For example, in the year 2012, the collection of the "Action among friends" was reverted to the restoration works of the church building itself. Besides the images and other data relevant to the festival, the leaflet brings information about the prizes for the participants: a motorbike, a bicycle, and three cash prizes. The tickets are always sold at popular prices to facilitate the participation of people from various social backgrounds. The prizes are usually obtained through donations. According to the interviewees, the Festa always "gives profit," because people are very generous. Marcos Antônio Oliveira states that, in the Festa in which he was emperor, in the year 2012, the church made quite a significant profit: "We sold all the raffles [Action among friends], we got more than 20 items for the auction. At the time, the profit was about 70 thousand, but if it were today, the party would have earned about 120 thousand. It was a good result" (Oliveira 2018b). According to Paulo Pimentel, a "strong" Festa depends on "strong" emperors, that is, "a well-known person that runs after things and has a good (financial) situation. For instance, at the time of the Festa, we need a car... then, if the emperor does not have it, we need to resort to someone else. The people who have a good financial situation end up getting things more easily. When the emperor is weak, the party is also weak. That is the truth!" (Pimentel 2018a).

Such attitude provokes diverse reactions among Holy Spirit devotees, as many understand that the financial issue should be, in fact, a secondary concern. However, they also acknowledge the fact that it is not. For Ludson Gonçalves, the success of the Festa should be related only to the spiritual issues, aiming at the maintenance of its religious essence. However, he recognizes that the current concern is centered, essentially, on the profit. For this reason, he claims that he started to attend only the religious part of the Festa, because he does not see any reasons to experience the secular part of the festivities (Gonçalves 2017).

Another controversial issue, repeated in several statements, is a need to establish prerequisites for candidacies for the positions of the emperors. Currently, there are no records of any formal requirements for those who apply for the lottery. This lack of precise criteria has generated certain discomfort among more conservative members of the community. Some interviewees affirm that people of other creeds, without religious experience and/or any links with the parochial community, may happen to be chosen, as the registration of candidates can be made up to a few minutes before the time of the draw. Felícia Pimentel Vieira, a frequent participant of the festival since childhood, argues: "Nowadays it is very loose. They don't put the prerequisites, but then they complain when people who don't understand anything about the Festa apply and end up being chosen" (Vieira 2018).

An example can be what happened during the 2018 festival. On the occasion, the emperor chosen for the year 2019, Julio Cezar Klaczok, was not even a Catholic. However, when he was chosen, he did attend the preparatory meetings, and in April 2019, he was baptized and received his First Eucharist. 
In the past, due to the great relevance of the Catholic religious festivals to the local community, the Feast of the Divine Holy Spirit and the Feast of Our Lady of Conception were officially included in the municipal budget. In this sense, it is also important to highlight the historical and political importance of this festival, which annually receives the support of the Municipal Public Power and the visit of local authorities. Currently, the financial support on behalf of the Municipality of Viana does not occur through transfers, as it was some time ago. Generally, the municipality supports the festivities by means of hiring some specialized service, for example, stage, sound, musical attraction, awnings, and graphics. However, the City Hall was officially authorized to transfer financial resources to help the festivities, according to the Law $\mathrm{N}^{\circ} 854 / 1976$ of the City Hall of Viana (Camara Municipal de Viana 1976).

The priest is responsible for the execution of the religious rituals and for the general coordination of the festival, together with the emperors and the organization team. In many things, depending on his personal attitude, he might have the power of decision and give the final word. During the interviews of laity, understanding of the direct relationship between the behavior of the priest and the success of the Festa was unanimous. In short, the greater his enthusiasm for the Festa execution, the greater the admiration of the community for his work.

Regarding the history of the Festa in Viana, Balestrero (2012) reports that it had been annual since 7 July 1817 until the year 1950, when the tradition was suddenly interrupted by the vicar of the time, Father Venâncio Toller (Balestrero 2012:99). This interval did not last for many years: "in 1953, we attended the Festa do Divino in Viana again" (Neves 2008:53). About this period, some elderly interviewees commented on the priests' excessive decision-making power in the past: there was no Festa because the priest did not like it and did not want it. "He was said to have participated in the War and was afraid of shootings and fireworks. If someone dropped something, he would get under wherever he was: under the table, under the bed. If he didn't want to, there was no Festa, even if the people wanted one. I think this occurred more than once" (Oliveira 2018a).

Those interviewees who had never heard of this fact, when questioned, showed resistance and revolt when asked about what would happen if, nowadays, some priest wanted to prohibit the Festa do Divino in Viana. According to Ana Maria Cavati, although the priest has much importance in the process of organization, currently, even if the priest did not want the Festa, it would not be allowed by the community, because "the Festa has already become a tradition" (Cavati 2018b).

When asked about the stance adopted by the priest who banned the Divino festivities in Viana, Father Adenilson Schimidt points out: "We are properly trained and oriented now so that we can insert ourselves in the context of the community. I think that nowadays that would be very unlikely to happen. There could even be some disagreements about which artist or band should perform, but to forbid the Festa altogether would be impossible. Today society no longer allows this. It is more active and democratic" (Schimidt 2018). Diva Salles, despite not remembering the fact itself, states that the attitude of the priest, to prohibit the festival, shows his ignorance. According to her, if nowadays any priest tried to do something similar, the Catholic community would certainly react (Salles 2018). In general, the 
interviewees agree that, nowadays, the power of an institutional church representative has become less evident, and inappropriate behavior of clergy instigates conflicts within the community, which often end up with the removal of a problematic priest.

Paulo Pimentel presents an interesting reflection regarding the reduction in the number of the Festa participants. He believes that, currently, many secular events compete with the Festa do Divino, and this ends up dividing the public, turning away attention even of those who would be interested just in the "profane" part of the Festa: "during my youth, this Festa was much awaited and families were anxious for its realization" (Pimentel 2018a). However, he points out that the Festa should in fact be, first of all, a religious event.

Asked about the "profane" part of the festivities, Father Adenilson Schimidt prefers using a more politically correct term "sociocultural part of the Festa"believes that the fact that the event has songs, dances and takes people to another dimension of conviviality should not necessarily be considered something "profane" meaning "inappropriate" (Schimidt 2018). He also explains that, during the years he was in Viana, no single fact occurred that could lead to questioning of the perpetuation of the Festa do Divino beyond the purely religious dimension (Schimidt 2018). For him, what happens outside of the temple is a continuation of what is celebrated in the temple, and its existence is a proof of the continuity of the religious aspect in social life. In the narrative of Father Adenilson, we perceive his criticism towards the "high degree of conservatism" present in the community. In a similar way, Father Luís Oggioni also prefers not to use the term "profane" talking about the Festa social program: "it is a very heavy word. I prefer to call it a popular party" (Oggioni 2018). Similarly, Vera Cavati, even considering the sacred part of the Festa most important, views the "profane" part as something positive, due to its strengthening of social ties in the community: "what strikes me most is that it's a day that brings people together. Not only inside the church, but also outside. Because people who come for the mass continue there after it is over. Then there is lunch time, when everyone meets. Sometimes you see people you haven't met for so long, and then there is a reunion. There are memories, many memories" (Cavati 2018c). As some people put it, pure fun is an important benefit that the Festa brings to the local community: "Reason for joy, besides preserving the tradition. Keeping the flame burning. At the end of it all, it brings joy to everyone. Everyone is very satisfied" (Oliveira 2018b).

However, for Ludson Gonçalves, who has attended the festival since he was a child, the profane or secular part of it is totally dispensable. According to him, the purely religious essence of the Festa is lost more and more every year, and social attractions, as well as people's behavior, do not match the religious atmosphere (Gonçalves 2017). These facts make him participate only in the religious rituals, as he considers that the secular (or profane) activities do not currently correspond to the religious sense that is expected of them: "I say that the profane party means breaking the link with the religious. What bothers me is exactly this: you go to a bar, you go to the profane part of the Festa and it is the same thing. So, this is a problem" (Gonçalves 2017). 
One of the ways to bring the community together for purely religious reasons was invention of a new tradition during the Festa: the ceremony of delivery of the flags of the seven gifts of the Holy Spirit. It is a mass with some insertions of readings and actions that refer to the Divine Holy Spirit, in which the emperors, as well as the families that take the flags home, receive a special blessing from the priest. The flags are made of red cloth and have the image of a dove of the Divine and the inscription of one of the gifts of the Holy Spirit painted white. The families hang them in front of the house and during the following week they organize meetings dedicated to praying together at home. According to information from the interviewees, the procession of the flags was initiated only in 2009 aiming at "increasing" religious rituals. In this way, the event could be classified as a "(re)invention of the tradition," according to Hobsbawm (2014), who applies this expression to various types of newly invented traditions, whether institutionalized or of short duration, if only such symbolic practices have the power to incorporate behaviors and values, and establish themselves, through repetition.

In this respect, Father Adenilson Schimidt also reports that, during his stay as a parish priest in the city of Viana, he "rescued" a tradition that, to his knowledge, belonged to the original Holy Spirit Festivities: "What I noticed is that over the years some of its experiences started getting lost. Before you had a visit that was made with the flag of the Holy Spirit in the houses... then, in Viana, it no longer existed and we tried to somehow rescue this..."(Schimidt 2018). However, this “(re) invented" by Father Adenilson Schimidt tradition currently no longer exists, but we perceive that the inclusion and exclusion of rituals and symbols are something quite recurrent in the Festa. Their appearance and permanence depend directly on those who are in charge of organization of the festivities. In this specific case, after the departure of Father Adenilson de Viana, his invention was abandoned. Father Adenilson also reports that he was responsible for another expressive modification during the celebrations: the change from triduum to novena: "In the festivals there was already the custom of making a triduum: three days of prayer and mass. Then I said: we do not have in our history the triduum, but the novena. So we are going to have a novena. At first there was some resistance on the part of the community, because they already had this idea of consolidating the triduum. Then we did the novena and they liked it very much. Then, every year we ended up doing it. I tried, even with my limitations, to rescue a little of this history and try to know a little more of the Festa do Divino and how it was originally celebrated by the Azorean immigrants" (Schimidt 2018).

From the speech of Father Adenilson, it is possible to perceive his strong inclination towards the search for the tradition, in a sense of making the Festa more faithful to how it was supposedly celebrated in the past. However, sometimes the return to such original traditions is difficult or simply impossible due to completely different circumstances - in this case the format chosen by the priest redefined total duration of the festivities, prolonging them for a week, which was unacceptable for the population, used to a more compact Festa, lasting approximately for up to five days.

Some testimonies pointed out that, in the past, the festival ended with a final procession. According to Nilza Cavati, "It was a very beautiful procession that ended in the church with a special blessing. To tell the truth, I think that the Feast should 
continue ending this way. Today it ends on the stage, with people dancing and singing" (Cavati 2018a). Also according to Marineuza Carvalho, "The Feast began and ended in a religious manner" (Carvalho 2018).

About the third, final procession, Cláudio Pimentel states that it ceased to exist around 1980s: "It used to take place in the afternoon, with the emperors, the faithful and the band. The route was to leave the church and go around the central part of Viana. I don't know why this has changed" (Pimentel 2018b).

Felícia Vieira, when asked about the main changes in the Festa do Divino, also mentions the existence of the third procession. However, in her account, she also mentions modifications in terms of the meals preparation: "on Sunday there was free lunch for everyone... After I became an adult, then it changed from water to wine... there are only things to sell" (Vieira 2018).

Some of the interviewees mentioned that, in the past, during the Festa, lunch was distributed among all the participants, without the need for any kind of payment. This characteristic reminds us of the origins of the Festa in the Azores, where, until today, everyone can serve themselves free of charge at all ceremonial meals. Also according to Maísa da Silva, through the reports she heard from Terezinha Nascimento, an old town resident: "there was a time when the family of the empress made the food and they donated it. Nobody bought anything, lunch was simply donated" (Silva 2018).

Currently, all the ingredients needed for the preparation of meals come from community donations and all income resulting from the sale of dishes is reverted to the parish. Maísa points out that, in the last Festa, the average number of sold lunches was 700 and adds: "In the year 2017, the team from Vila Velha donated lunch. This year (2018), we made the lunch ourselves. It's up to us to decide what to do, but it changes from year to year" (Silva 2018).

\section{Conclusions}

The strength of popular Catholic religiosity in Brazil manifests itself in a great number of religious festivals. Among them, devotion to the Divine Holy Spirit marks intensely local religious calendars and parochial sociability patterns, structuring the representative and identity relations of Catholic communities, especially in places originally inhabited by the Azorean immigrants, who brought and disseminated this Portuguese medieval cultural heritage. For a long time, it was preserved, almost unchanged, in various regions of Brazil. However, in recent decades, the modifications and transformations in the Festa organization have, indeed, been many. For the sake of the paper, we analyzed just four of them, emphasizing their sociocultural aspects and possible determinants.

Partly by means of existing bibliography research, partly through our own handson experience drawn from the fieldwork, we presented differences and peculiarities of the Holy Spirit festivities in these places, as well as their recent and current transformations. We could observe that these festivities, characterized by the fluidity between sacred and profane rituals, have been constantly shaped to fit best in the new social and cultural characteristics and changing needs of local communities. 
During our research, we confirmed the hypothesis that sociocultural factors have had indeed a considerable impact over these popular religious festivals: the Festa do Divino can be viewed not only as a set of religious rituals, but also as an important social interaction mechanism, including diverse sociocultural phenomena, in which local identities, power relations, and structures are constantly produced and negotiated. Among the most notable changes in the contemporary execution of the Festa are the decrease of public the participating in purely religious ceremonies, mainly during processions and masses, which made it necessary, for instance, to shorten the time of the Festa by means of resigning from traditional novenas and some other, more time-consuming, traditional activities of social and popular religiosity character (folias); competition between religious and profane parts of the Festa, with much more stress put recently on secular activities that attract crowds (dinners, auctions, dances, concerts); the excessive concern with financial profit that the Festa should produce to sustain the parish by means of lotteries, charged meals, sales of donated prizes, and bingo games; implementation in many places of the system of commercial sponsorship of the Festa, enforcing the necessity to provide publicity for the sponsors and attract both locals and tourists who could make such an investments successful; and loosening of social control over the community members and liberalization of the rules of conduct during the Festa celebrations (presence of alcohol, problem with musical bands and their repertoire, problems around indicating the emperors, lack of proper, elegant clothing, etc.). It was also possible to confirm the occurrence of several changes, e.g., new elements incorporated or old ones subtracted from the traditional celebration script of the Festa do Divino in Viana. In many statements, especially of the elderly, there is a tone of nostalgia when they refer to the Festa of "old times," i.e., the one kept in their memories, which used to be a great and very much expected and respected community event, much more traditional, with deeply embedded Azorean cultural ingredients, but at the same time, apparently much more egalitarian (free meals for all the participants, for instance). Some people mention also visible changes in terms of the relationships between the Catholic clergy and the organizers on the part of the community (the Festa commission or parochial councils): nowadays, it seems that laity has often an upper hand in making final decisions about the directions the Festa should take and priests' ideas and proposals are not always followed without discussionsometimes they are openly criticized, opposed, or turned down and their initiatives-forgotten or ignored. The same could be observed in relation to the roles of the emperors, who are nowadays sometimes considered to be "puppets" of the Festa, as they have no real say in many organizational things that they historically controlled. An interesting conclusion is also that the clergy representatives seem indeed much more liberal than many of their parishioners, especially in terms of, often criticized, secular parts of the Festa celebrations.

Therefore, although it is a religious festival, there are disagreements on many issues among its participants, sometimes even evolving into more serious conflicts, which put the realization of the Festa itself into danger. It would be a mistake to think that all community members will always act in perfect harmony just because they are experiencing an event of religious character. Such conflicts are and will 
always be present, though sometimes they may seem camouflaged. They show that the Festa is a very good barometer of all other sociocultural phenomena and processes taking place within a given community.

Last but not least, in many narratives, there was also a recurrent regret with respect to the scarce participation of young people, who more and more often show their preference for other, more attractive forms of socializing, while avoiding religious rituals of the festivities as old-fashioned. The interviewees often express their concern that the tradition may not be passed on and further perpetuated due to the lack of interest on the part of the next generation. Therefore, this paper may also serve as an academic testimony to its importance and a necessity of protection.

Supplementary Information The online version contains supplementary material available at https://doi. org/10.1007/s41603-021-00150-6.

Open Access This article is licensed under a Creative Commons Attribution 4.0 International License, which permits use, sharing, adaptation, distribution and reproduction in any medium or format, as long as you give appropriate credit to the original author(s) and the source, provide a link to the Creative Commons licence, and indicate if changes were made. The images or other third party material in this article are included in the article's Creative Commons licence, unless indicated otherwise in a credit line to the material. If material is not included in the article's Creative Commons licence and your intended use is not permitted by statutory regulation or exceeds the permitted use, you will need to obtain permission directly from the copyright holder. To view a copy of this licence, visit http://creativecommons.org/licen ses/by/4.0/.

\section{References}

Araújo A (1964) Festas, bailados, mitos e lendas, vol V. 1. Melhoramentos, São Paulo

Bakhtin M (1987) A cultura popular na Idade Média e no Renascimento: o contexto de François Rabelais. UnB, Brasília

Balestrero HL (2012) Subsídios para o estudo da geografia e da história do município de Viana. JEP Gráfica, Vitória

Berger P (2005) Święty baldachim. Nomos, Cracow

Brandão CR (1985) Memórias do sagrado: estudos de religião e ritual. Ed. Paulinas, São Paulo

Câmara Municipal de Viana (1976) Lei n 854 de 10 de dezembro de 1976. http://www3.camaraviana.es. gov.br/Arquivo/Documents/legislacao/html/L8541976.html. Acessed $08 \mathrm{dez} 2018$

Carvalho M (2018) Marineuza Carvalho (Tia Neuzinha): Interview [29 Aug. 2018]. Interviewer: Fabiene Passamani Mariano. Viana/ES

Cavati NC (2018a) Nilza Carvalho Cavati: Interview [30 Aug. 2018]. Interviewer: Fabiene Passamani Mariano. Viana/ES

Cavati AM (2018b) Ana Maria Cavati: Interview [03 Sept. 2018]. Interviewer: Fabiene Passamani Mariano. Viana/ES

Cavati VLM (2018c) Vera Lúcia Cavati Moreira (Verinha): Interview [19 Jun. 2018]. Interviewer: Fabiene Passamani Mariano. Viana/ES

Costa A (1999) O Poder e as Irmandades do Espírito Santo. Açores: DRC: Ed. Rio dos livros

Costa A (2008) O Culto do Espirito Santo. Esquilo edições e multimídia, Lisboa

Cruz JO (2018) A festa do Divino Espírito Santo em Gravataí/RS: ao longo dos séculos XX - XXI. Novas Edições Acadêmicas, San Bernardino

Gonçalves LJ (2017) Ludson Gonçalves de Jesus: Interview [25 Nov. 2017]. Interviewer: Fabiene Passamani Mariano. Viana/ES

Guarinello NL (2001) Festa, trabalho e cotidiano. In: Jancsó I, Kantor I (Orgs.) Festa: cultura e sociabilidade na América portuguesa 2v. Imprensa Oficial, São Paulo 
Hobsbawm EJ (2014) Invenção das tradições. Paz e Terra, Rio de Janeiro Leal J (2017) O culto do divino: migrações e transformações. Edições 70, Lisboa

Moore RL (1994) Selling god: American religion in the marketplace of culture. OUP, New York

Moraes FO (2003) A Festa do Divino em Mogi das Cruzes: folclore e massificação na sociedade contemporânea. Annablume/Fapesp, São Paulo

Neves GS (2008) Coletânea de estudos e registros do folclore capixaba: 1944-1982. Centro Cultural de Estudos e Pesquisas do Espírito Santo, Vitória

Oggioni L (2018) Luís Oggioni: Interview [14 Aug. 2018]. Interviewer: Fabiene Passamani Mariano. Viana/ES

Oliveira MB (2018a) Márcio Balestrero de Oliveira: Interview [20 Aug. 2018]. Interviewer: Fabiene Passamani Mariano. Vitória/ES

Oliveira MA (2018b) Marcos Antônio Oliveira: Interview [14 Aug. 2018]. Interviewer: Fabiene Passamani Mariano, Viana/ES

Pacheco G, Gouveia C (2005) Caixeiras do Divino Espírito Santo de São Luís do Maranhão. Associação Cultural Caburé, Rio de Janeiro

Pereira MN (1989) O Sahiré e o Marabaixo. Recife: Fundaj, Massangana

Pimentel PR (2018a) Paulo Roberto Pimentel (Paulinho Pimentel): Interview [27 Aug. 2018]. Interviewer: Fabiene Passamani Mariano. Viana/ES

Pimentel C (2018b) Cláudio Pimentel: Interview [09 Oct. 2018]. Interviewer: Fabiene Passamani Mariano. Viana/ES

Salles DL (2018) Diva Lyrio Salles: Interview [28 Aug. 2018]. Interviewer: Fabiene Passamani Mariano. Viana/ES

Schimidt AA (2018) Adenilson Antônio Schimidt: Interview [19 Aug. 2018]. Interviewer: Fabiene Passamani Mariano. Vitória/ES

Silva ML (2018) Maísa Lourdes da Silva: Interview [25 Aug. 2018]. Interviewer: Fabiene Passamani Mariano. Viana/ES

Siuda-Ambroziak R (2019) Prosperity gospel on the rise - development and expansion of neo-Pentecostal churches in Brazil. In: Ramos de Andrade S, Siuda-Ambroziak R, Stachowska E (Eds.) BrazilPoland. Focus on Religion. UEM, Maringá

Siuda-Ambroziak R, Passamani Mariano F (2020) Açorianidade e brasilidade nas Festas do Divino: o caso de Viana (ES). Revista del CESLA: International Latin American Studies Review (26):83-110. https://doi.org/10.36551/2081-1160.2020.26.83-110

Stark R, Bainbridge WS (2000) Teoria religii. Nomos, Cracow

Stark R, Finke R (2002) Beyond church and sect: dynamics and stability in religious economies, In: Jelen TG (Ed.) Sacred Markets, Sacred Canopies. Essays on Religious Markets and Religious Pluralism. Rowman and Littlefield Publishers Inc., Maryland

Steil CA (2016) Traditional popular Catholicism in Brazil. In: Schmidt BE, Engler S (orgs.) handbook of contemporary religions in Brazil. Brill, Leiden/Boston

Vieira FP (2018) Felícia Pimentel Vieira: Interview [03 Oct. 2018]. Interviewer: Fabiene Passamani Mariano. Viana/ES

Zaluar A (1983) Os homens de Deus: um estudo dos santos e das festas no catolicismo popular. Zahar Editores, Rio de Janeiro

Publisher's Note Springer Nature remains neutral with regard to jurisdictional claims in published maps and institutional affiliations. 